\title{
DRUNKEN VIOLENCE AND THE TRANSITION OF POWER IN Plutarch's AlEXANDER
}

\author{
JefFrey Beneker \\ University of Wisconsin, Madison
}

\begin{abstract}
This essay compares two episodes from Plutarch's Alexander: the wedding of Philip and Cleopatra (9) and Alexander's attack on Cleitus (50-51). The wedding episode, in which an angry, drunken Philip attacks Alexander, foreshadows Alexander's own attack on Cleitus, but it also marks an important turning point in the development of the young Alexander. Prior to the wedding episode, Plutarch portrays Alexander as highly rational, wise beyond his years, and eager to rule. In creating this image, Plutarch uses Philip as a foil, showing how Alexander was better suited than his father to be king and how he had grown restless in his role as heir. Thus their clash over insults traded at the wedding party is the result of a rift in the fatherson relationship and is intimately tied both to the positive and negative aspects of Alexander's character and to the transition of power between father and son ${ }^{1}$.
\end{abstract}

The Life of Alexander fits quite well with the theme of the symposium, since, according to Plutarch, Alexander was a drinker by nature and made a habit of spending late nights at drinking parties. There are two episodes in particular that feature symposiastic settings and appear to be significant to the overall structure of the biography. The first is the wedding party from chapter nine, where a drunken Philip draws his sword on Alexander, and the second is the drinking party in chapters 50 and 51, where a drunken Alexander attacks and kills his friend Cleitus. Others, including Judith Mossman and John O'Brien, have argued convincingly for a relationship between these episodes, showing how Philip's attempt on Alexander's life prefigures Alexander's drunken assault on Cleitus later in the book'. In this essay, I will take that idea as a starting point and then argue further that Plutarch has used both episodes to mark important transitions in Alexander's acquisition and use of power.

Let me begin by summarizing very briefly the relevant details of both episodes. Philip's wedding party is on the surface a relatively straightforward affair. Philip has married a young Macedonian woman - too young perhaps, since Plutarch says that Philip loved her $\pi \alpha \rho^{\prime} \dot{\eta} \lambda ı$ เíav, contrary to his age. At the wedding banquet, the bride's uncle, Attalus, urges the guests to pray that this marriage produce a legitimate heir to the throne. Alexander is insulted by the insinuation that he, the present heir, is illegitimate, and he verbally rebukes Attalus and throws his cup at him. Philip immediately rises up, draws his sword, and charges his son, but "luckily for both men Philip tripped and fell

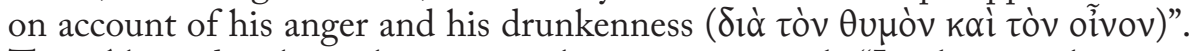
Then Alexander closes the scene with a cutting remark: "Look, men, this man is making preparations to cross from Europe into Asia, but he's been tripped up

\footnotetext{
${ }^{1}$ I would like to thank Craig Gibson, who read earlier drafts of this paper and provided helpful comments and criticism.

2 J. M. Mossman, 1988, p. 86 (= 1995, p. 215); J. M. O’Brien, 1992, p. 139.
} 
crossing from one couch to another". Following this confrontation, Alexander leaves Macedonia, moving his mother to Epirus and biding his time among the Illyrians.

At its core, the second episode is quite similar to the first in that it involves drunkenness and anger, but there is an important difference as well. At the wedding, Philip and Alexander escaped disaster because they both were lucky

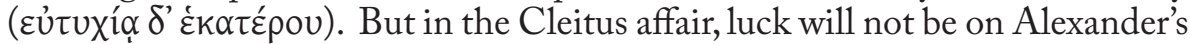
side. Plutarch writes that, "if we consider both the cause and the moment, we discover that the king did not act according to a plan, but through some

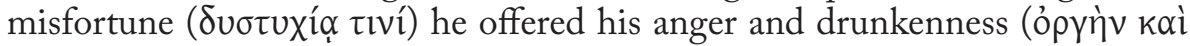
$\mu \varepsilon \dot{\theta}(\eta v)$ as an excuse to the daemon of Cleitus". The critical elements of the story are as follows: at a drinking party, Alexander and Cleitus begin to fight after Cleitus is offended by a song that ridicules some Macedonian generals; he then goes on to mock Alexander for being subservient to the Persians; in a rage, Alexander seeks his sword and calls his body guard, but these are withheld and Cleitus is rushed from the room; he returns, however, chanting yet another insult, and Alexander runs him through with a spear. As soon as Cleitus falls

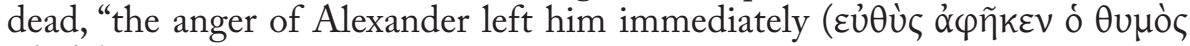

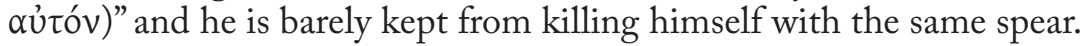

Mossman rightly says that, "Philip's drunken attempt to attack Alexander is a doublet of the death of Cleitus". Before making a forward comparison to the Cleitus episode, however, I would like to look backward to the preceding chapters on Alexander's youth. For the wedding scene represents not only a foreshadowing of Alexander's own drunken and angry violence, but also the culmination of a rather complex character portrait that Plutarch has been sketching over the course of several chapters. The young Alexander whom we meet at the wedding party has been cast as highly rational, wise beyond his years, and ready to rule. In creating this image, Plutarch uses Philip as a foil, showing how Alexander was better suited than his father to be king and how he had grown restless in his role as heir apparent. Thus their clash over the insults traded between Attalus and Alexander is the result of a much deeper divide in the father-son relationship and is intimately tied to both the positive and the negative aspects of Alexander's nature.

Plutarch introduces a fundamental element of his portrait of Alexander in the well-known passage from chapter two, where Philip has a dream in which he is closing his wife's womb with a seal that bears the image of a lion. Aristander the seer interprets the dream correctly when others cannot: Philip's wife Olympias is pregnant with a child who will possess a lion-like and a

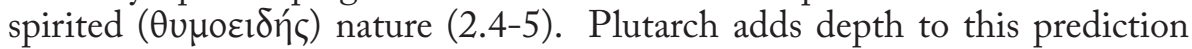
in chapter four, where he explains the origins and implications of Alexander's spiritedness, adds that he also possessed temperance ( $\sigma \omega \varphi \rho \circ \sigma u ́ v \eta)$ with regard to pleasures of the body, and introduces a discussion of Alexander's ambition (4.7-11). Plutarch does not dwell on the first two elements of Alexander's nature, but he uses the remaining element, his ambition, to make two important points. First, he asserts that the young Alexander's ambition was exceptional 
for his age and so kept his thought or purpose "weighty and high-minded"

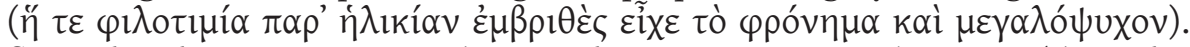
Second and more important, he introduces a comparison between Alexander and Philip that runs through several chapters, up to and including the wedding episode in chapter nine.

Plutarch introduces this comparison ostensibly to support his point about Alexander's high-mindedness, but it becomes the vehicle for a more detailed sketch of his character. Plutarch begins by explaining that Alexander's seriousness of purpose made him discriminating when it came to building his reputation:

For Alexander did not love glory of every kind or from every source, as Philip did, who adorned himself sophistically with cleverness of speech ( $\lambda$ óyou $\tau \varepsilon$ $\delta \varepsilon ı v o ́ \tau \eta \tau \imath ~ \sigma o \varphi ı \sigma \tau ı k \tilde{\omega} \zeta ~ \kappa \alpha \lambda \lambda \omega \pi \imath \zeta o ́ \mu \varepsilon v o \zeta)$ and engraved his chariot victories at Olympia on his coins; but when those around Alexander kept asking if he wished to compete in the footrace at the Olympic games, since he was a fast runner, he said, "Sure, if I would have kings as competitors" (4.9-10).

The comparison in this passage is somewhat surprising, because Plutarch has claimed that Alexander's ambition was $\pi \alpha \rho$ ' $\dot{\eta} \lambda ı k i ́ \alpha v$, contrary to his age. We might have expected an example of how Alexander surpassed one or more of his young companions in high-minded and weighty thoughts. Instead, he surpasses even his father, a point that Plutarch seems eager to press. He tells us that Philip took pride in his success at the Olympic games; then he has Alexander denigrate this sort of victory as being beneath a king. Plutarch is referring to the years of Alexander's youth, and so his ambition is certainly contrary to his age, but his high-minded remark also distinguishes him from his father, the king that he will eventually replace. Comparing this passage to the wedding episode, we cannot help but notice that Alexander was ambitious

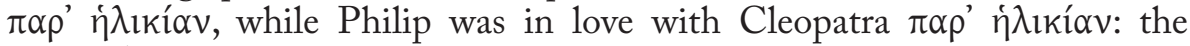
young Alexander exceeds expectations, while the mature Philip fails to meet them. Between these two points in the biography, Plutarch builds his case for Alexander's superiority.

Philip, according to the passage above, not only celebrated his Olympic victories, but he also "adorned himself sophistically with cleverness of speech". Plutarch takes up this point again after the quip about kings as competitors, going on to say that Alexander was generally disinterested "in the race of athletes" but preferred instead to stage contests for tragedians, musicians, hunters and men who fought with rods (4.11). Plutarch is creating an antithesis here between displays of physical skill and intellectual skill, with Alexander showing an obvious preference for the intellectual over the physical. Plutarch does not claim that Alexander, who is fast enough to compete at Olympia, had disdain for athletics, but only that he preferred to be around intellectual types. Philip, on the other hand, eager for any type of glory, settled for sophistries, just as he proudly won Olympic victories against lesser competitors. 
This discussion leads directly to an anecdote, in chapter five, that reinforces the intellectual prowess of Alexander in comparison with Philip. An embassy from the Persian king arrives in Macedonia while Philip is absent. Alexander meets the visitors and does not question them as a young, inexperienced man would, but he makes serious inquiries about the Persian king, his military strength, and the geography of the Asian interior. As a result of his questioning, the ambassadors "were amazed and thought that the legendary cleverness of

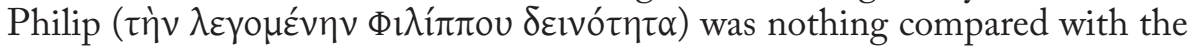
boy's eagerness and his inclination to do great deeds". As with the example from the previous chapter, this comparison with Philip is not automatic. Alexander does not ask "any small or childish question", so the Persians might naturally have compared him to other young men his age. But as Plutarch narrates the anecdote, in their eyes Alexander is superior even to Philip, who is again relegated to the intellectual backseat, enjoying a reputation for cleverness, but as a leader paling in comparison with his son.

Plutarch rounds out this chapter by exposing the tension between Alexander's "inclination to do great deeds" and his lack of real political power. He describes him as agitated when he hears of Philip's victories in war, and worried that his father will leave him nothing to conquer (5.4-6). He also describes two of Alexander's teachers, pointing out that one, Leonidas, was called Alexander's foster-father ( $\tau \rho \circ \varphi \varepsilon u ́ \varsigma)$ and the other, Lysimachus, referred to himself as Phoenix, to Alexander as Achilles, and to Philip as Peleus (5.7-8). There is no doubting who is best in that trio, and so for a third time Alexander is compared favorably to his father. Moreover, the description of both teachers serves to emphasize that Alexander's education is making him independent of Philip, and while being heir limits his opportunity to act, at least for the moment, it does not limit the potential of his nature. This notion is reinforced in anecdotes that appear in subsequent chapters, when Alexander is reported to have said that he had life on account of Philip but a virtuous life on account of Aristotle (8.4); and when the Macedonians, as a result of Alexander's military success at age sixteen and his actions at the battle of Chaeronia, call Alexander their king but Philip their general $(9.4)^{3}$.

There is an additional anecdote that precedes the wedding episode and that fleshes out Alexander's rational nature and his relationship to Philip. This is the famous taming of Bucephalas in chapter six. Philip Stadter and Tim Whitmarsh have shown that the Platonic undertone of this passage fits well with Plutarch's emphasis on the philosophical education of Alexander ${ }^{4}$. All Philip's men are unable to break the horse, and when Philip decides to send the animal away, Alexander charges that the men are soft and inexperienced. In response, Philip confronts his youthful son, saying, "Are you reproaching your elders, as though you know more or are better able to control the horse?".

\footnotetext{
${ }^{3}$ Looking even farther ahead, when Cleitus is insulting Alexander at the drinking party, he accuses Alexander of rejecting Philip and promoting the idea that Zeus Ammon was his real father (50.11).

${ }^{4}$ P. A. Stadter, 1996, pp. 293-4; T. Whitmarsh, 2002, pp. 180-1.
} 
Alexander does, in fact, know more than the others. Rather than try to break the horse physically, as Philip's men had done, Alexander observes the horse's behavior, recognizes that it fears its own shadow, and then turns the horse (Platonically, as Whitmarsh says) toward the sun and masters it with relative ease. Once he succeeds, Philip joins other characters of this Life in acknowledging Alexander's superiority: "My son," he says, "seek a kingdom that is your equal, because Macedonia cannot contain you!" It seems reasonable to take Philip's words as prophetic and to look ahead to Alexander's war against the Persian empire, and so this episode says something important about Alexander's future campaigns as well as his nature: he will conquer Persia not by force alone but mainly by wisdom, and he will succeed where Philip would have failed. Taking Philip's declaration together with Alexander's cutting remarks about racing at Olympia, the reaction of the Persian ambassadors, and the Macedonians' praise of Alexander's leadership, we are encouraged to conclude that Philip was a great general, but that Alexander was the king who could compete with Darius. By the time we arrive at the wedding scene, Alexander himself is impatient enough to confront Philip with the truth.

Thus the wedding scene is the culmination of an extended comparison of Alexander to Philip. However, in addition to putting Philip in his place, Alexander also reacts angrily and impulsively to the insult of Attalus. This reaction is at odds with the portrait that Plutarch has been creating: apart from describing Alexander's spirited and thirsty nature in chapter four, he has presented his hero as rational and controlled. The discussion of his philosophical interests and his training under Aristotle, which comes in chapters seven and eight, between the taming of Bucephalas and the wedding episode, only reinforces this point. Looking backward from the murder of Cleitus, the precedent set by Philip's attack on Alexander is obvious, but the embarrassment of Philip at the end of the scene overshadows Alexander's anger, so that on its own, the wedding scene is not particularly foreboding.

There is, however, an anecdote in the very next chapter that also demonstrates Alexander's tendency to act out of anger and further complicates the picture of a rational hero. The marriage of Philip to Cleopatra and the insult of Attalus raised doubts for Alexander about his standing in the family. When he hears that Pixodarus, the king of Caria, is planning to marry his daughter to Philip's other son, Arrhidaeus, he becomes upset and he makes arrangements to marry the daughter himself. Philip discovers his plan and chastises him, explaining that such a marriage was beneath him. In contrast to the disagreement over the taming of Bucephalas, Philip is right about the Carian princess, and Alexander is wrong. More important, Alexander's behavior reveals that when he is suspicious or feels slighted, his judgment may be confused - $\delta 1 \alpha \tau \alpha \rho \alpha \chi \theta \varepsilon i ́ \zeta$, Plutarch writes - and he may act in an irrational manner. In this case, he has acted more like Philip at the Olympic games, seeking out the glory of a royal marriage even to the daughter of a lesser man.

${ }^{5}$ Of the extant accounts, Plutarch is the first to report Philip's prophecy; see A. R. Anderson, 1930, pp. 17-21. 
This scene, even more than the drunken fight with Philip, casts an ominous shadow over Alexander's future, and both together serve as background for his angry attack on Cleitus in response to a perceived insult ${ }^{6}$.

Looking forward to the Cleitus episode, Plutarch has left no doubt that Alexander is acting irrationally in attacking his friend: he says at the start that the event was not premeditated (oủk ómò $\gamma v \omega \dot{\mu} \mu \eta$ ) and at the end that

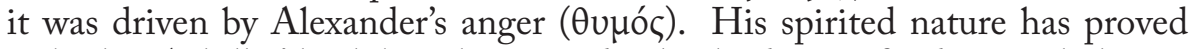
to be his Achilles' heel, but this episode also leads to a fundamental change in Alexander's behavior and even his character. As Whitmarsh has written, the Cleitus episode ushers in a reevaluation of Alexander's relationship to philosophy, and it is therefore no coincidence that the murder takes place in a symposiastic setting. "If Plato's and Xenophon's Symposia constitute the paradigms of philosophical friendship, then the Clitus episode represents the negative image of such serenity and self-control"'. What better way to represent Alexander's break with his philosophical past than an angry, lethal fight at a symposium $^{8}$. Plutarch, in fact dwells for several chapters on philosophical matters following the murder. In order to relieve Alexander's suffering, the philosopher Anaxarchus convinces him that he is a law unto himself and therefore need feel no shame for killing Cleitus. This argument, according to Plutarch, relieved Alexander's suffering, but it also changed him, making "his ethos in many respects chaunoteron and more lawless" (52.7). "Chaunoteron" in this passage may mean "more frivolous" or "more conceited", but in either case, it represents a departure from the Alexander that we met in the early chapters, whose ambition kept his thoughts weighty and high-minded. In fact, Alexander has not only acted like Philip in attacking his friend; in heeding Anaxarchus' sophistic justification for the murder and becoming chaunoteron, he has actually become more like Philip, whom Plutarch described as vain and adorned with sophistic cleverness, and who Alexander charged was unfit to invade Asia as a result of his drunken stumble. As Alexander looks forward to a new campaign in India, this is certainly not a positive development ${ }^{10}$.

Plutarch also describes here the severing of ties between Alexander and Aristotle, even though this happened at a later time. He writes that Alexander

${ }^{6}$ E. D. CARney, 1992, examines both the wedding episode and the Pixodarus affair for their historical accuracy but without fitting them into Plutarch's larger narrative.

${ }^{7}$ T. Whitmarsh, 2002, p. 183.

${ }^{8}$ Excessive drunkenness was not a rare event at a typical Macedonian drinking party (see E. N. Borza, 1983), and so we may view Alexander's behavior as not only a break with his philosophical training but also a return to his more basic instincts.

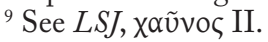

${ }^{10}$ The Cleitus affair is by no means the first irrational moment for Alexander following the incident at Philip's wedding and the attempt to arrange a marriage with Pixodarus' daughter, but like the wedding episode, it represents the climactic moment in an extended illustration of Alexander's character. In Plutarch's narrative, Alexander becomes more violent and irrational as his reign progresses, and he is always susceptible to rash behavior when he suspects an insult;

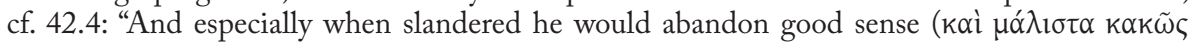

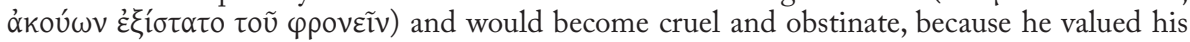
reputation above his life and his kingdom”. See B. Buszard, 2008, pp. 189-90. 
had a falling out with Callisthenes, the great-nephew of Aristotle, and eventually Callisthenes was implicated in the pages conspiracy, for which Alexander put him to death (53-55). Plutarch quotes from a letter in which Alexander vows to punish not only Callisthenes, but also "those who sent him and who are harboring in their cities conspirators against me". Plutarch says that by this letter, Alexander "openly revealed himself as being against Aristotle" in whose home Callisthenes had been raised (55.7-8). Alexander once said that Philip gave him life, but Aristotle gave him a virtuous life; now he accuses Aristotle of supporting a conspiracy to kill him, rejecting his philosophical father in order to preserve the life that his ordinary father, Philip, had granted him.

All of this happens, as Plutarch admits, much later, but by narrating the break with Aristotle immediately following the murder of Cleitus, Plutarch encourages the reader to consider them together. And when Plutarch steers his narrative thread back to the present, he does so with an anecdote that ties the Cleitus affair back to the wedding scene and makes a point about transitions in leadership. Following the confrontation at the wedding in chapter nine, Alexander left Macedonia for Illyria. Straightaway, Demaratus the Corinthian visits Philip and chides him for inquiring about the political situation in Greece when he cannot keep his own household in order (9.1214). This counsel leads Philip to recall Alexander; then the very next chapter narrates the affair with Pixodarus and Philip's murder. Thus Demaratus plays a small but critical role in the transition of power from father to son.

Following the murder of Cleitus, Plutarch inserts the digression on Callisthenes and Aristotle; then the wise Demaratus returns again in chapter 56, this time expressing pity for the Greeks who died before seeing Alexander on the throne of Darius. Then he also dies. This anecdote is poignant, but it seems out of place, because Demaratus has already made this observation, in chapter 37, when Alexander sat on Darius' throne for the first time at Persepolis. In his commentary, J. R. Hamilton remarks that the good treatment that Demaratus receives from Alexander is meant to stand in contrast to the harsh treatment of Callisthenes ${ }^{11}$. This is no doubt true, but this final appearance by Demaratus leaves an ominous impression. As Plutarch has constructed the narrative, Demaratus was on hand to facilitate or to mark Alexander's surpassing of two kings, Philip and Darius. By returning a third time, after Alexander has killed his friend Cleitus in anger, developed a more frivolous character, and made a formal break with his philosophical past, he signals a less hopeful transition: it seems that he can die now because he has seen Alexander at his peak. The ascent toward high-minded glory began when Alexander declared that the stumbling Philip was unfit to invade Asia, and it has ended with Alexander's own drunken assault on Cleitus, which serves as a warning that he, too, may now be unfit for the campaigns that lie ahead.

The very next chapter opens with Alexander's preparations to make a crossing into India. He will accomplish amazing things, to be sure, but his

\footnotetext{
${ }^{11}$ J. R. Hamilton, 1969.
} 
behavior will continue to deteriorate and he will eventually lose control of his army. Thus both the wedding scene and the Cleitus affair signal important transitions in the personality of Alexander and in the leadership of the Macedonians. The fight at the wedding marks the ascendance of Alexander while at the same time revealing a crack in his rational foundation. The violent disruption of the symposium, and the concomitant rejection of philosophical

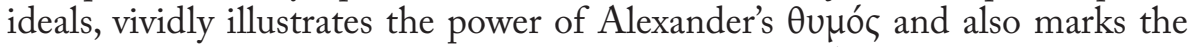
beginning of his decline as king. In the Cleitus affair, Alexander has taken the role that his father played in the wedding episode, but rather than yield to a better man, as Philip did after his drunken mistake, Alexander gives way to a lesser version of himself.

\section{WORKS CITED}

Anderson, A. R., “Bucephalas and his Legend”, AJPh, 51 (1930) 1-21.

Borza, E. N., “The Symposium at Alexander's Court”, Archaia Makedonia, 3 (1983) 45-55.

Buszard, B., “Caesar's Ambition: A Combined Reading of Plutarch's Alexander-Caesar and Pyrrhus-Marius", TAPhA, 138 (2008) 185-215.

Carney, E. D., "The Politics of Polygamy: Olympias, Alexander and the Murder of Philip", Historia, 41 (1992) 169-89.

Hamilton, J. R., Plutarch: Alexander, A Commentary, Oxford, 1969.

Mossman, J. M., “Tragedy and Epic in Plutarch's Alexander”, JHS, 108 (1988) 83-93. (reprinted in Scardigli, B. (ed.), Essays on Plutarch's Lives, Oxford, 1995, pp. 209-28)

O'Brien, J. M., Alexander the Great: The Invisible Enemy, London, New York, 1992.

Stadter, P. A.,"Anecdotes and the Thematic Structure of Plutarchean Biography”, in Fernández Delgado, J. A. \& Pordomingo Pardo, F. (eds.), Estudios sobre Plutarco: Aspectos Formales. Actas del IV Simposio Español Sobre Plutarco (Salamanca, 26-28 de Mayo, 1994), Madrid, 1996, pp. 291-303.

Whitmarsh, T., “Alexander's Hellenism and Plutarch's Textualism”, CQ, 52 (2002) 174-92. 